\title{
ANALISIS KEMAMPUAN PEMECAHAN MASALAH BERDASARKAN TEORI KRULIK DAN RUTNICK DALAM MENGERJAKAN SOAL OLIMPIADE OLEH SISWA SMP
}

\author{
Trimahesti1), Kriswandani2), Novisita Ratu ${ }^{3)}$ \\ 1Pendidikan Matematika, Universitas Kristen Satya Wacana Salatiga, 202014101@student.uksw.edu \\ 2Pendidikan Matematika, Universitas Kristen Satya Wacana Salatiga, kriswandani@staff.uksw.edu \\ 3Pendidikan Matematika, Universitas Kristen Satya Wacana Salatiga, novisita.ratu@staff.uksw.edu
}

\section{INFO ARTIKEL}

Riwayat Artikel:

Diterima: 04-03-2018

Disetujui: 19-03-2018

\section{Kata Kunci:}

Geometri ruang

Krulik-Rudnick

Pemecahan masalah

Olimpiade

\begin{abstract}
ABSTRAK
Abstrak: Penelitian ini adalah penelitian deskriptif kualitatif, yang bertujuan untuk mengetahui kemampuan pemecahan masalah matematika dalam mengerjakan soal olimpiade SMP bagi siswa kelas IX SMP N 8 Salatiga. Subjek penelitian terdiri dari 4 siswa yang dipilih dengan teknik purposive sampling. Berdasarkan hasil tes dan wawancara diketahui semua subjek tidak memenuhi kelima tahap Krulik \& Rudnick pada soal nomor 1. Pada langkah awal tahap membaca dan berfikir (read and think) subjek telah melakukan kesalahan dalam memahami soal/masalah. Sedangkan untuk soal nomor 2 hanya 1 subjek yang tidak mampu melewati tahap kelima pada tahap teori Krulik dan Rudnick yaitu refleksi dan pengembangan (reflect and extend).
\end{abstract}

\begin{abstract}
This is a qualitative descriptive research. The purpose of this research is to know the ability of mathematics problem solving in doing Junior High Olympics for students of grade IX SMP N 8 Salatiga. The research subjects consist of 4 students selected by purposive sampling technique. Based on the results of tests and interviews are known that all subjects did not meet the five stages of Krulik \& Rudnick in question number 1. In the first step of reading and thinking phase, the subject has made a mistake in understanding the problem. Meanwhile, in question number 2 only 1 subject who is not able to pass the fifth stage at the stage of Krulik and Rudnick theory, that is reflect and extend.
\end{abstract}

\section{A. LATAR BELAKANG}

Matematika membantu manusia dalam memahami dan mengatasi permasalahan. Kline (1973 dalam R. Rohisah Verial, dkk 2014: 101-102) menyatakan bahwa matematika bukanlah pengetahuan menyendiri yang dapat sempurna karena dirinya sendiri, tetapi adanya matematika dapat membantu manusia dalam memahami dan mengatasi permasalahan sosial, ekonomi dan alam.

Tujuan diberikan pelajaran matematika di tingkat pendidikan dasar dan pendidikan menengah salah satunya adalah memberi bekal peserta didik untuk mempunyai kemampuan pemecahan masalah (Permendiknas, 2006). Lebih lanjut Charles dan O'Daffer dalam Harahap E R \& Edi S (2017: 44) menyatakan bahwa tujuan diajarkannya pemecahan masalah dalam belajar matematika adalah 1) mengembangkan keterampilan berpikir siswa; 2) mengembangkan kemampuan menyeleksi dan menggunakan strategi-strategi penyelesaian masalah; 3) mengembangkan sikap dan keyakinan dalam menyelesaikan masalah; 4) mengembangkan kemampuan siswa menggunakan pengetahuan yang saling berhubungan;
5) mengembangkan kemampuan siswa untuk memonitor dan mengevaluasi pemikirannya sendiri dan hasil pekerjaannya selama menyelesaikan masalah; 6) mengembangkan kemampuan siswa menyelesaikan masalah dalam suasana pembelajaran yang bersifat kooperatif; dan 7) mengembangkan kemampuan siswa menemukan jawaban yang benar pada masalah-masalah yang bervariasi.

Kemampuan pemecahan masalah merupakan ketrampilan yang penting dilatihkan kepada siswa. Hal tersebut sejalan dengan pendapat Pujiadi dalam Purnomo dan Mawarsari (2014: 2) yang mengungkapkan bahwa kemampuan memecahkan masalah adalah tujuan utama dalam pembelajaran matematika, oleh karena itu kemampuan memecahkan masalah hendaknya diberikan, dilatihkan, dan dibiasakan kepada siswa sedini mungkin. Akan tetapi, pada kenyataanya pembelajaran matematika belum sesuai dengan yang diharapkan. Pembelajaran matematika yang ada sekarang masih berpusat pada guru dan tidak membiasakan siswa melatih kemampuan 
pemecahan masalahnya. Hal itu terlihat dari hasil pekerjaan siswa seperti berikut :

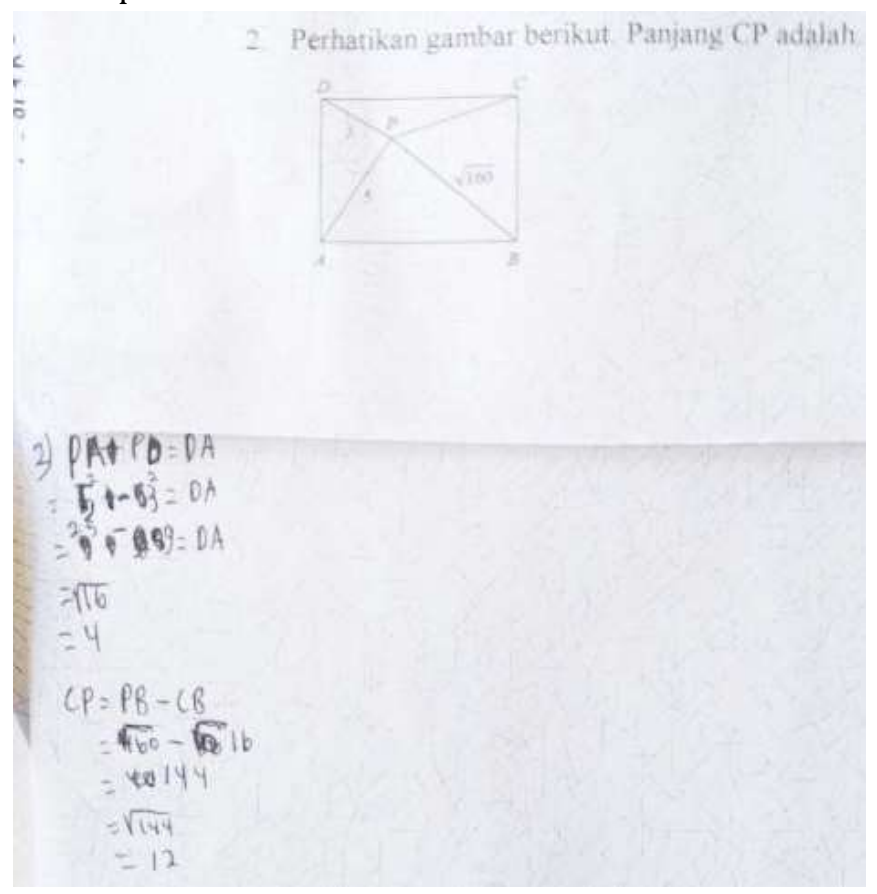

Gambar 1. Bukti Hasil Pekerjaan Siswa

Melaui gambar diatas, hal tersebut siswa tidak menuliskan apa yang dia ketahui namun siswa mengerti yang ditanyakan, artinya siswa sudah bisa memahami masalah. Siswa tersebut juga tidak menuliskan rumus, artinya siswa tersebut tidak membuat rencana penyelesaiannya. Walaupun pada hasil perhitungannya yang dilakukan siswa tersebut, memang benar namun dari banyaknya coret-coretan yang terlihat bahwa siswa ragu dengan yang ia terima dikelas sehingga bisa dikatakan dalam pembelajaran yang pasif dan hanya melihat serta mendengar saat guru menjelaskan materi. Akibatnya dalam mengerjakan soal siswa hanya terpaku mengikuti contoh yang diberikan oleh guru. Sejalan dengan hal itu, Rousseau dalam Handayani D \& Rusdiana A (1986) menyatakan bahwa setiap orang yang belajar harus aktif sendiri, tanpa ada aktifitas proses pembelajaran tidak akan terjadi. Hal ini didukung oleh hasil penelitian Thorndike mengemukakan keaktifan belajar siswa dalam belajar dengan hukum "law of exercise"-nya menyatakan bahwa belajar memerlukan adanya latihan-latihan dan Mc Keachie menyatakan berkenaan dengan prinsip keaktifan mengemukakan bahwa individu merupakan "manusia belajar yang aktif selalu ingin tahu" (Dimyati,2009: 45).

Kemampuan pemecahan masalah siswa dapat diketahui berdasarkan tahap-tahap pemecahan masalah. Krulik dan Rudnik (1996) dalam Murdiana N (2015) mengenalkan lima tahapan pemecahan masalah sebagai heuristik, lima langkah tersebut adalah: 1) membaca dan berpikir (read and think), aktifitas yang dilakukan siswa pada tahap ini adalah mencatat kata kunci, bertanya kepada siswa lain apa yang sedang ditanyakan pada masalah, atau menyatakan kembali masalah ke dalam bahasa yang lebih mudah dipahami; 2) eksplorasi dan merencanakan (explore and plan), tahap ini siswa mengidentifikasi masalah yang diberikan, menyajikan masalah ke dalam cara yang mudah dipahami; 3) memilih strategi (select a strategy), pada tahap ini, siswa menarik kesimpulan atau membuat hipotesis mengenai bagaimana cara menyelesaikan masalah yang ditemui berdasarkan apa yang sudah diperoleh pada dua tahap pertama; 4) mencari jawaban (find and answer), pada tahap ini semua keterampilan matematika seperti menghitung dilakukan untuk menemukan suatu jawaban; dan 5) refleksi dan pengembangan (reflect and extend), pada tahap ini siswa mengecek kembali jawabannya dan melihat variasi dari cara memecahkan masalah. Oleh karena itu, siswa harus dihadapkan dalam berbagai masalah matematika agar kemampuan pemecahan masalah siswa dapat dilatih.

Menurut Wahyudi dan Budiono (2012: 80) pada umumnya masalah matematika dapat dibedakan menjadi dua macam, yaitu masalah rutin dan masalah nonrutin. Masalah rutin adalah soal latihan yang dapat diselesaikan dengan prosedur yang dipelajari di kelas atau prosedurnya umum diketahui. Masalah jenis ini banyak terdapat dalam buku ajar dan dimaksudkan hanya untuk melatih siswa menggunakan prosedur yang sedang dipelajari di kelas. Masalah nonrutin adalah soal yang dalam proses menyelesaikannya diperlukan pemikiran lebih lanjut karena prosedurnya tidak sama dengan prosedur yang dipelajari di kelas. Dengan kata lain, masalah nonrutin ini menyajikan situasi baru yang belum pernah dijumpai oleh siswa sebelumnya. Situasi baru tersebut memuat tujuan yang jelas yang akan dicapai, tetapi cara mencapainya tidak segera muncul dalam benak siswa. Contoh masalah nonrutin adalah soal uraian olimpiade.

Berdasarkan paparan diatas maka penelitian ini bertujuan untuk mendeskripsikan kemampuan pemecahan masalah siswa berdasarkan teori Krulik dan Rudnick pada soal olimpiade kelas IX SMP N 8 Salatiga.

\section{B. METODE PENELITIAN}

Jenis penelitian yang digunakan adalah penelitian deskriptif kualitatif. Penelitian ini mendiskripsikan kemampuan pemecahan masalah berdasarkan teori Krulik dan Rutnick dalam mengerjakan soal olimpiade oleh siswa SMP. Subjek dalam penelitian ini adalah 4 siswa kelas IX SMP N 8 Salatiga yang memiliki kemampuan berpikir tinggi. Pengambilan subjek dalam penelitian ini dengan cara purposive sampling, dimana subjek dipilih berdasarkan kriteria tertentu. Pemilihan subjek penelitian ini didasari oleh pertimbangan bahwa siswa kelas IX telah memiliki pengalaman belajar yang cukup dan dibuktikan oleh nilai hasil belajar siswa berdasarkan raport atau rekomendasi dari guru. Sehingga diharapkan dapat menyelesaikan soalsoal tentang pemecahan masalah terkhusus pada soal olimpiade. 
Metode untuk pengambilan data dalam penelitian ini adalah metode dokumentasi, metode tes, dan metode wawancara. Dalam metode tes, tes yang digunakan berupa soal pemecahan masalah olimpiade matematika materi geometri ruang yang terdiri dari 2 soal uraian. Teknik analisis data dalam penelitian ini menggunakan teknik analisis menurut Sugiyono (2013: 337) yaitu reduksi data, penyajian data dan penarikan kesimpulan. Instrumen utama dalam penelitian ini adalah peneliti sendiri dan pedoman wawancara. Analisis data dalam ini meliputi reduksi data, penyajian data dan penarikan kesimpulan, sedangkan pengujian keabsahan data dalam penelitian ini menggunakan teknik triangulasi teknik dan waktu.

\section{HASIL DAN PEMBAHASAN}

Hasil penelitian menunjukkan bahwa tahap pemecahan masalah yang dilakukan subjek penelitian berdasarkan tahapan Krulik dan Rudnick (1) Membaca dan berpikir (read and think), (2) Mengeksplorasi dan merencanakan (explore and plan), (3) Memilih suatu strategi (select a strategy), (4) Menemukan suatu jawaban (find an answer), (5) Meninjau kembali dan mendiskusikan (reflect and extend). Subjek dalam penelitian ini adalah 4 siswa yang dikategorikan dalam siswa berkemampuan tinggi.

Berdasarkan teori Krulick dan Rudnik maka dapat dilihat dari hasil analisis data kemampuan pemecahan masalah matematika siswa dalam menyelesaikan soal olimpiade adalah sebagai berikut:

\section{Kemampuan Pemecahan Masalah S1}

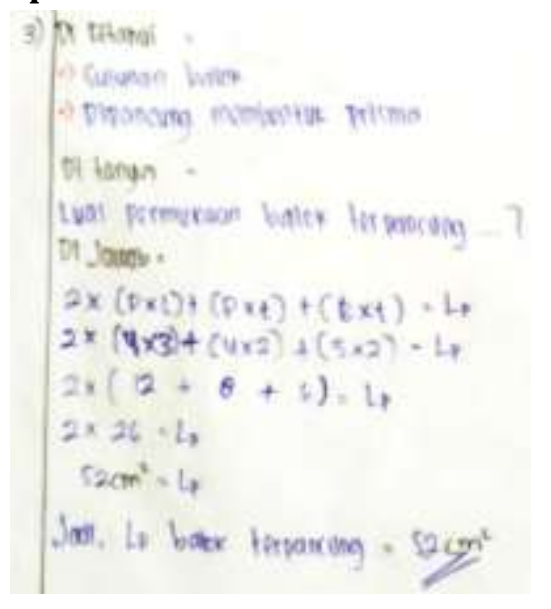

Gambar 2. Hasil Pekerjaan S1 Soal No 1

Berdasarkan hasil jawaban tertulis S1 diatas, S1 tidak dapat memahami soal dengan baik. Hal itu terlihat melalui proses dan hasil pemecahan masalah S1 yang hanya menghitung bangun pemancung. S1 membuat rencana dengan menggunakan rumus luas balok yaitu 2 kali penjumlahan antara panjang kali lebar tambah panjang kali tinggi ditambah lebar kali tinggi. Masing-masing nilai panjang, lebar, dan tinggi didapatkan dengan menghitung tiap kubus satuan, namun S1 tidak menyebutkannya secara tertulis melainkan secara lisan, diantaranya adalah panjang 4 satuan, lebar 3 satuan dan tinggi 2 satuan. Keempat komponen tersebut dihitung berdasarkan prisma yang terbentuk pada balok. Kemudian S1 memasukkan angka kedalam rumus menjadi 2 dikali penjumlahan 4 kali 3 , ditambah 4 kali 2, ditambah 3 kali 2. Sehingga, 2 dikali 26 sama dengan $52 \mathrm{~cm}^{2}$. Menurut S1 bangun yang terpancung adalah bangun yang membentuk prisma segitiga, namun bangun tersebut kurang tepat karena prisma pada gambar soal merupakan bangun pemancung. Sedangkan masalah yang ditanyakan dalam soal adalah luas balok yang terpancung. Mengacu pada jawaban tersebut dapat dikatakan bahwa S1 tidak paham akan apa yang diketahui dan ditanyakan dari soal. Hal ini diperkuat dengan petikan wawancara dengan $\mathrm{S} 1$ seperti berikut:
$\mathrm{P} \quad$ : "Oke langsung aja lanjut pada soal no 1, dari soal no 1 apa aja yang kamu ketahui dari soal no 1?"
S1 : "Yaitu susunan balok yang di pancung membentuk prisma."
P : "Kemudian apa yang ditanyakan dari soal no 1"
S1 : "Luas permukaan balok terpancung"
$\mathrm{P} \quad$ : "Ee, rencananya, rencana untuk menjawab soal no 1 itu bagaimana?
S1 : "Yaitu untuk, ee mencari rumus dari luas prisma yaitu $2 \times(p l+p t+l t)$ dan disitu diketahui bahwa panjangnya adalah ee, panjangnya yaitu dengan mengukur balok itu dan jumlahnya adalah 4 dan lebarnya 3, ee kemudian tingginya 2. Dan saya memasukkanya dirumus tersebut sehingga menghasilkan jawaban $52 \mathrm{~cm}^{2}$ "
$\mathrm{P} \quad$ : "Kan disitu ditulis $2 \times(p l+p t+l t)$ itu rumus apa?"
S1 : "Luas balok"
$\mathrm{P} \quad$ : "Luas balok? Trus kamu kok bisa menyebutkan bahwa panjang itu 4, lebar itu 3 darimana?"
S1 : "Lha kan pada soalnya kan ada gambar ee balok dari susunan kubus-kubus kecil nah saya menghitung dari kubus-kubusnya"
$\mathrm{P} \quad$ : "Owh gitu, ee dari jawabanmu tadi apakah kamu sudah mengecek kembali?"
S1 : "Sudah,"
$\mathrm{P} \quad$ : "Kamu udah yakin dengan jawabanmu?"
S1 : "Sudah".

Oleh karena itu, berdasarkan hasil jawaban tertulis dan wawancara S1 tersebut dapat diidentifikasi bahwa S1 tidak mampu melakukan kelima tahap Krulik dan Rudnick. Hal itu terjadi karena pada langkah awal yaitu tahap membaca dan berfikir saja S1 telah melakukan kesalahan dalam memahami soal atau masalah. Sehingga pada tahap selanjutnyapu S1 tidak dapat melanjutkan proses pemecahan masalah dengan benar.

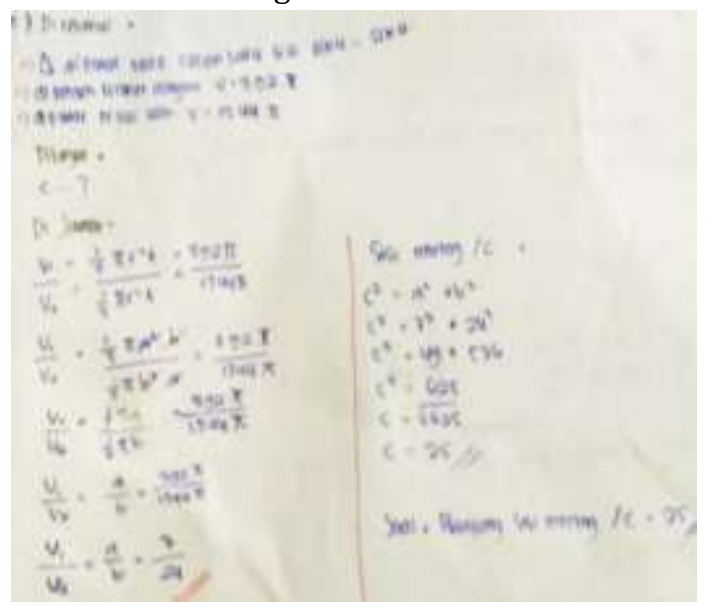

Gambar 3. Hasil Pekerjaan S1 Soal No 2 
Berdasarkan hasil pekerjaan S1 diatas, untuk mencari panjang sisi miring segitiga atau $c$, langkah awal yang dilakukan S1 yaitu menuliskan bahwa terdapat segitiga yang diputar pada salah satu sisi siku-siku akan membentuk kerucut. Kerucut pertama memiliki volume $392 \pi \mathrm{cm}^{3}$ dan volume kedua memiliki volume $1344 \pi \mathrm{cm}^{3}$. Kemudian langkah selanjutnya S1 membuat rencana dengan menggunakan rumus volume kerucut yaitu $V=$ $\frac{1}{3} \pi \cdot r^{2} \cdot t$, selain itu S1 juga menggunakan rencana lain dengan perbandingan. Berdasarkan gambar yang tertera pada soal sisi $a$ pada kerucut 1 merupakan jari-jaridan sisi $b$ pada kerucut 1 merupakan tinggi begitu pula sebaliknya pada kerucut 2, maka melalui rumus volume diatas S1 memanipulasi menjadi $V_{1}=\frac{1}{3} \pi \cdot b^{2} \cdot a=392 \pi$ dan $V_{2}=$ $\frac{1}{3} \pi \cdot a^{2} \cdot b=1344 \pi$. Kemudian S1 memandingkan kedua volume serta menyederhanakan angka atau huruf yang sama dengan cara mencoret atau menghilangkan. Hal itu terlihat dari hasil jawaban S1 yaitu $\frac{V_{1}}{V_{2}}=\frac{a}{b}=\frac{392}{1344}$ kemudian kedua volume dibagi dengan angka yang sama yaitu 56 sehingga nilai $\frac{V_{1}}{V_{2}}=\frac{a}{b}=\frac{7}{24}$. Berdasarkan hasil akhir S1 beranggapan bahwa sisi $a=7$ dan sisi $b=24$ sehingga untuk mencari sisi miring $c$, S1 menggunakan rumus Pythagoras dimana rumus tersebut adalah $c^{2}=\sqrt{a^{2}+b^{2}}$. Kemudian S1 memasukkan angka pada rumus tersebut sehingga $c^{2}=\sqrt{7^{2}+24^{2}}$, sehinggga sisi $c=\sqrt{625}=25$, jadi panjang sisi miring segitiga siku-siku tersebut adalah $25 \mathrm{~cm}$.

Mengacu pada jawaban tersebut dapat dikatakan bahwa S1 paham akan apa yang diketahui dan ditanyakan dari soal, S1 juga sudah memiliki gambaran atau rencana pada soal yang dikerjakan serta dapat mengimplementasikan keterampilan matematika dengan cara menghitung mundur untuk menemukan suatu jawaban. Hal ini diperkuat dengan petikan wawancara dengan S1 seperti berikut:

P : : "Okey dari soal no 2, apa aja yang kamu ketahui dari soal no 2?"

S1 : "Segitiga diputar pada salahsatu sisi siku-siku diperoleh kerucut dengan volume $392 \pi$ diputar kesisi lain volumenya tigabel ee, $1344 \pi^{\prime \prime}$

$\mathrm{P} \quad$ : "Kemudian apa yang ditanyakan dari soal ini?"

S1 : "Sisi c"

$\mathrm{P} \quad$ : "Rencana untuk menjawab soal ini itu apa yang kamu gunakan?"

$\mathrm{S} 1 \quad$ : "Ee... saya mencari rumus yaitu $\frac{v_{1}}{v_{2}}$ dan volume dari volume segitiga ee volume dari kerucut 1 itu yaitu $392 \pi$ dan volume dari segitiga 2 yaitu $1344 \pi$ dengan rumus seperti $v=\frac{1}{3} \pi r^{2} t$ dan disitu saya memasukkan angka-angkanya dengan $\frac{v_{1}}{v_{2}}=\frac{\frac{1}{3} \pi a^{2} b}{\frac{1}{3} \pi b^{2} a}=$ $\frac{392 \pi}{1344 \pi}, "$

P : "Okey berhenti dulu disitu, kamu kok tadi menggunakan rumus $\frac{1}{3} \pi r^{2}$ t mengapa pada langkah selanjutnya kok berubah menjadi $\frac{1}{3} \pi a^{2} b$ ?"

S1 : "Karena $r$ disitu merupakan jari-jari pada kerucut yang merupakan alas segitiga a dan $t$ disitu merupakan tinggi kerucut yang merupakan tinggi segitiga juga yang saya anggap $b^{\prime \prime}$

$\mathrm{P} \quad$ : "Oke kemudian setelah kamu membandingkan langkah selanjutnya yang kamu gunakan bagaimana, antara ini dengan ini?"

S1 : "Mencoret huruf yang sama yaitu $b$ dengan $b^{2}$ dan a dengan $a^{2}$ sehingga menghasilkan $\frac{v_{1}}{v_{2}}=\frac{\pi a}{\pi b}=\frac{392 \pi}{1344 \pi}$,"

$\mathrm{P} \quad$ : "Lalu kan itu kan udah menjadi $\frac{v_{1}}{v_{2}}=\frac{\pi a}{\pi b}=\frac{392 \pi}{1344 \pi}$ kenapa pada langkah selanjutnya $\frac{v_{1}}{v_{2}}=\frac{a}{b}=\frac{7}{24}$ ?"

S1 : "Ee... $\frac{v_{1}}{v_{2}}=\frac{a}{b}=\frac{7}{24}$...ee karena, $\frac{7}{24}$ merupakan bentuk sederhana dari $\frac{392 \pi}{1344 \pi}$."

$\mathrm{P}$ : "Berarti cara untuk menentukan $\frac{7}{24}$ dengan menyederhanakan?"

S1 : "Eee... menyederhanakan dengan cara membagi dengan angka yang sama"

$\mathrm{P} \quad$ : "Oke lalu rencana selanjutnya?"

S1 : "Yaitu mencari sisimiring atau c yaitu dengan cara rumus Pythagoras sama dengan $c^{2}=a^{2}+b^{2}$, ee $c^{2}=7^{2}+24^{2}$ menjadi $c^{2}=49+576, c^{2}=625$, lalu $c=\sqrt{625}$, jadi menghasilkan 25 , jadi sisi miring merupakan 25"

P : "Oke dari jawabanmu tadi apakah sebelumnya kamu sudah mengecek kembali?"

S1 : "Sudah"

Berdasarkan hasil jawaban tertulis dan wawancara S1 tersebut dapat diidentifikasi bahwa S1 telah melakukan usaha awal dalam memahami soal serta dapat menganalisis hal-hal yang perlu digunakan dalam proses pemecahan masalah dengan cara mengaitkan pada pengetahuan sebelumnya yaitu volume kerucut, perbandingan, dan rumus pythagoras. Kemudian S1 menggunakan cara bekerja mundur atau mencoba mengerjakan melalui perhitungan dan penyederhanaan serta melakukan penarikan kesimpulan hasil jawaban yang berarti S1 telah melakukan pengecekan kembali. Oleh karena itu dapat disimpulkan bahwa S1 mampu melewati kelima tahap Krulick dan Rudnik yaitu membaca dan berpikir dimana pada langkah ini S1 melakukan identifikasi fakta, pertanyaan, serta menjelaskan setting. Kemudian mengeksplorasi dan merencanakan dinama S1 mengorganisasikan semua informasi yang di perlukan, memilih suatu strategi dimana S1 mencoba mengerjakan serta menyederhanakan sehingga permasalahan menjadi lebih sederhana, dan menemukan suatu jawaban dimana S1 menggunakan kemampuan berhitungnya dan meninjau kembali.

\section{Kemampuan Pemecahan Masalah S2}

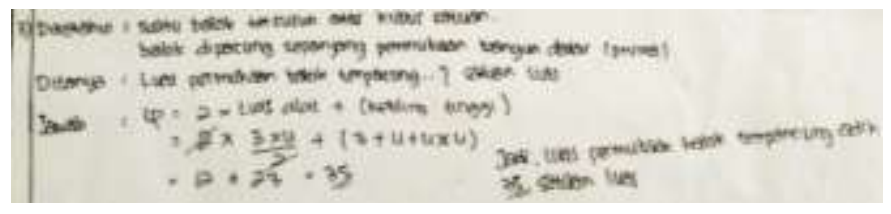

Gambar 4. Hasil Pekerjaan S2 Soal No 1

Berdasarkan hasil jawaban tertulis S2 diatas, S2 tidak dapat memahami soal dengan baik. Hal itu terlihat melalui proses dan hasil pemecahan masalah bahwa S2 yang hanya 
menghitung bangun pemancung. S2 membuat rencana dengan menggunakan rumus luas prisma yaitu 2 kali luas alas tambah keliling tambah tinggi. Masing-masing nilai panjang, lebar, dan tinggi didapatkan dengan menghitung tiap kubus satuan, namun S2 tidak menyebutkannya secara tertulis melainkan secara lisan, diantaranya adalah panjang 4 satuan, lebar 3 satuan dan tinggi 2 satuan. Keempat komponen tersebut dihitung berdasarkan prisma yang terbentuk pada balok. Kemudian S2 memasukkan angka pada rumus dengan masing-masing angka 2 kali 3 kali 4 dibagi 2 ditambah 3 tambah 4 tambah 4 kali 4 sama dengan 35 satuan luas. Menurut S2 bangun yang terpancung adalah bangun yang membentuk prisma segitiga, namun bangun tersebut kurang tepat karena prisma pada gambar soal merupakan bangun pemancung. Sedangkan masalah yang ditanyakan dalam soal adalah luas balok yang terpancung. Mengacu pada jawaban tersebut dapat dikatakan bahwa S2 tidak paham akan apa yang diketahui dan ditanyakan dari soal. Hal ini diperkuat dengan petikan wawancara dengan S2 seperti:

$\mathrm{P} \quad$ : "Pada soal no 1, apa aja yang diketahui dari soal no $1 ? "$

S2 : "Yang diketahui itu ada suatu balok yang tersusun atas kubus satuan, dan balok tersebut dipancung sepanjang permukaan bangun datar yang berbentukkan prisma"

$\mathrm{P} \quad$ : "Terus apa yang ditanyakan pada soal no 1?"

S2 : "Yang ditanya berapa luas permukaan balok yang terpancung dengan satuan luas atau balok yang dipotong"

$\mathrm{P} \quad$ : "Kemudian rencana apa yang kamu gunakan untuk mencari jawaban tersebutr?"

S2 : "Dengan cara mencari luas ee mencari luas prisma dengan menggunakan rumus prisma, karena balok yang dipancung itu merupakan bentuk prisma."

P : "Oke coba jelaskan cara adek mencari jawaban dengan rumus prisma."

S2 : "Rumus luas prisma itu 2 kali luas alas ditambah keliling ditambah tinggi, sama dengan $\frac{2.3 .4}{2}+3+4+$ 4 x 4 hasilnya yaitu 12 ditambah 23 yaitu 35, dengan menghitung kotak-kotak yang tersusun atas prisma tersebut jadi luas permukaan balok yang terpancung adalah 35 luas dengan satuan."

P : : "Adik tadikan menyebutkan 2 kali 3 kali 4 nah yang ingin saya tanyakan angka-angka itu dari mana?"

S2 : "Ee, berasal dari hitungan, hitungan apa kotak-kotak yang menyusun prisma"

P : "Okey, dari jawaban adek apakah sebelumnya sudah di cek kembali."

S2 : "Sudah"

Oleh karena itu, berdasarkan hasil jawaban tertulis dan wawancara S2 tersebut dapat diidentifikasi bahwa S2 tidak melakukan kelima tahap Krulik dan Rudnick. Hal itu terjadi karena pada langkah awal yaitu tahap membaca dan berfikir saja S2 telah melakukan kesalahan dalam memahami soal atau masalah. Sehingga pada tahap selanjutnyapu S2 tidak dapat melanjutkan proses pemecahan masalah dengan benar.

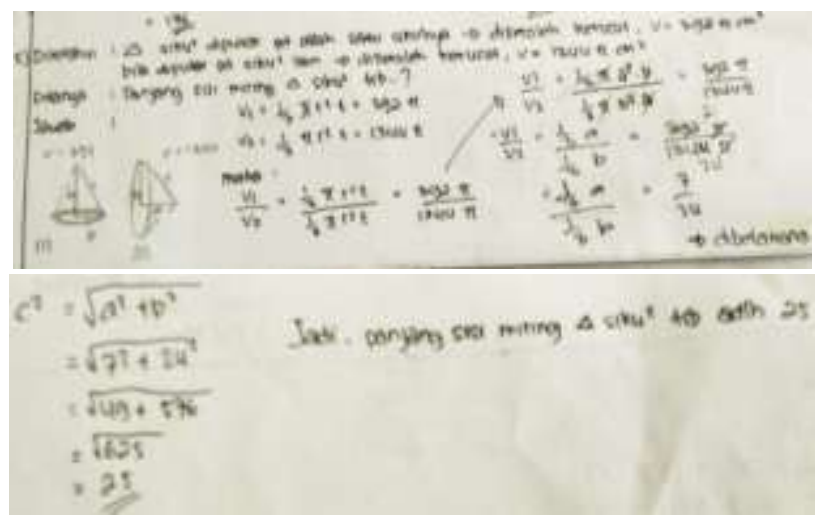

Gambar 5. Hasil Pekerjaan S2 Soal No 2

Berdasarkan hasil pekerjaan S2 diatas, untuk mencari panjang sisi miring segitiga atau $c$, langkah awal yang dilakukan S2 yaitu menuliskan bahwa terdapat segitiga yang diputar pada salah satu sisi siku-siku akan membentuk kerucut. Kerucut pertama memiliki volume $392 \pi \mathrm{cm}^{3}$ dan volume kedua memiliki volume $1344 \pi \mathrm{cm}^{3}$. Kemudian langkah selanjutnya S2 membuat rencana dengan menggunakan rumus volume kerucut yaitu $V=$ $\frac{1}{3} \pi \cdot r^{2} \cdot t$, selain itu $\mathrm{S} 2$ juga menggunakan rencana lain dengan perbandingan. Berdasarkan gambar yang tertera pada soal sisi $a$ pada kerucut 1 merupakan jari-jaridan sisi $b$ pada kerucut 1 merupakan tinggi begitu pula sebaliknya pada kerucut 2, maka melalui rumus volume diatas S2 memanipulasi menjadi $V_{1}=\frac{1}{3} \pi \cdot b^{2} \cdot a=392 \pi$ dan $V_{2}=$ $\frac{1}{3} \pi \cdot a^{2} \cdot b=1344 \pi$. Kemudian S2 memandingkan kedua volume serta menyederhanakan angka atau huruf yang sama dengan cara mencoret atau menghilangkan. Hal itu terlihat dari hasil jawaban S2 yaitu $\frac{V_{1}}{V_{2}}=\frac{a}{b}=\frac{392}{1344}$ kemudian kedua volume dibagi dengan angka yang sama yaitu 56 sehingga nilai $\frac{V_{1}}{V_{2}}=\frac{a}{b}=\frac{7}{24}$. Berdasarkan hasil akhir S2 beranggapan bahwa sisi $a=7$ dan sisi $b=24$ sehingga untuk mencari sisi miring $c$, S2 menggunakan rumus Pythagoras dimana rumus tersebut adalah $c^{2}=\sqrt{a^{2}+b^{2}}$. Kemudian S2 memasukkan angka pada rumus tersebut sehingga $c^{2}=\sqrt{7^{2}+24^{2}}$, sehinggga $\operatorname{sisi} c=\sqrt{625}=25$, jadi panjang sisi miring segitiga siku-siku tersebut adalah $25 \mathrm{~cm}$

Mengacu pada jawaban tersebut dapat dikatakan bahwa S2 paham akan apa yang diketahui dan ditanyakan dari soal, S2 juga sudah memiliki gambaran atau rencana pada soal yang dikerjakan serta dapat mengimplementasikan keterampilan matematika dengan cara menghitung mundur untuk menemukan suatu jawaban. Hal ini diperkuat dengan petikan wawancara dengan S2 seperti berikut:

P : : "Okey untuk selanjutnya apa yang kamu ketahui dari soal no 2?"

S2 : "Yang saya ketahui itu ada segitiga siku-siku yang diputar pada salah satu siku-sikunya yang diperoleh kerucut dengan volume $392 \pi \mathrm{cm}^{2}$ dan bila diputar pada siku-siku lain diperoleh kerucut dengan volume $1344 \pi \mathrm{cm}^{2}$."

P : "Oke dari soal no 5 apa yang ditanyakan?" 


\section{$\frac{v_{2}}{\pi b}=\frac{392 \pi}{1344 \pi}$}

$\mathrm{P} \quad$ : "Lalu kan itu kan udah menjadi $\frac{v_{1}}{v_{2}}=\frac{\pi a}{\pi b}=\frac{392 \pi}{1344 \pi}$ kenapa pada langkah selanjutnya $\frac{v_{1}}{v_{2}}=\frac{a}{b}=\frac{7}{24}$ ?"

S2 : "Ee... $\frac{v_{1}}{v_{2}}=\frac{a}{b}=\frac{7}{24}$ ee karena, $\frac{7}{24}$ merupakan bentuk sederhana dari $\frac{392 \pi}{1344 \pi}$. “

$\mathrm{P}$ : "Berarti cara untuk menentukan $\frac{7}{24}$ dengan menyederhanakan?"
S2 : "Eee...menyederhanakan dengan cara membagi dengan angka yang sama"

$\mathrm{P} \quad$ : "Oke lalu rencana selanjutnya?"

S2 : "Yaitu mencari sisimiring atau c yaitu dengan cara rumus Pythagoras sama dengan $c^{2}=a^{2}+b^{2}$, ee $c^{2}=7^{2}+24^{2}$ menjadi $c^{2}=49+576, c^{2}=625$, lalu $c=\sqrt{625}$, jadi menghasilkan 25, jadi sisi miring merupakan 25"

Berdasarkan hasil jawaban tertulis dan wawancara S2 tersebut dapat diidentifikasi bahwa S2 telah melakukan usaha awal dalam memahami soal serta dapat menganalisis hal-hal yang perlu digunakan dalam proses pemecahan masalah dengan cara mengaitkan pada pengetahuan sebelumnya yaitu volume kerucut, perbandingan dan teorema pythagoras. Kemudian S2 menggunakan cara bekerja mundur atau mencoba mengerjakan melalui perhitungan dan penyederhanaan serta melakukan penarikan kesimpulan hasil jawaban yang berarti S2 telah melakukan pengecekan kembali. Oleh karena itu dapat disimpulkan bahwa S2 mampu melewati kelima tahap Krulick dan Rudnik yaitu membaca dan berpikir dimana pada langkah ini S2 melakukan identifikasi fakta, pertanyaan, serta menjelaskan setting. Kemudian mengeksplorasi dan merencanakan dinama S2 mengorganisasikan semua informasi yang di perlukan, memilih suatu strategi dimana S2 mencoba mengerjakan serta menyederhanakan sehingga permasalahan menjadi lebih sederhana, dan menemukan suatu jawaban dimana S2 menggunakan kemampuan berhitungnya dan meninjau kembali.

\section{Kemampuan Pemecahan Masalah S3}

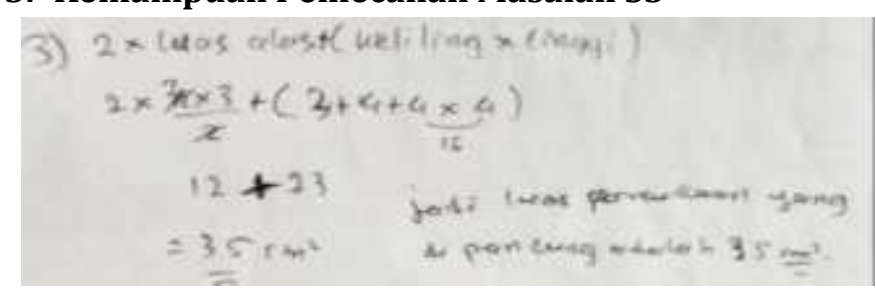

Gambar 6. Hasil Pekerjaan S3 Soal No 1

Berdasarkan hasil jawaban tertulis S3 diatas, S3 tidak dapat memahami soal dengan baik. Hal itu terlihat melalui proses dan hasil pemecahan masalah bahwa S3 yang hanya menghitung bangun pemancung. S2 membuat rencana dengan menggunakan rumus luas prisma yaitu 2 kali luas alas tambah keliling tambah tinggi. Masing-masing nilai panjang, lebar, dan tinggi didapatkan dengan menghitung tiap kubus satuan, namun S2 tidak menyebutkannya secara tertulis melainkan secara lisan, diantaranya adalah panjang 4 satuan, lebar 3 satuan dan tinggi 2 satuan. Keempat komponen tersebut dihitung berdasarkan prisma yang terbentuk pada balok. Kemudian S2 memasukkan angka pada rumus dengan masing-masing angka 2 kali 3 kali 4 dibagi 2 ditambah 3 tambah 4 tambah 4 kali 4 sama dengan $35 \mathrm{~cm}^{2}$. Menurut S3 bangun yang terpancung adalah bangun yang membentuk prisma segitiga, namun bangun tersebut kurang tepat karena prisma pada gambar soal merupakan bangun pemancung. Sedangkan masalah yang ditanyakan dalam soal adalah luas balok yang terpancung. Mengacu pada jawaban tersebut dapat dikatakan bahwa S3 tidak paham akan apa yang diketahui dan ditanyakan dari soal. Hal ini diperkuat dengan petikan wawancara dengan S3 seperti: 
P : "Untuk soal no 1 yang diketahui atau kamu pahami dari soal no 1 apa aja?"

S3 : "Disoal no 1 itu kan gambar balok-balok hanya bisa menemukan balok-baloknya atau menghitung balokbaloknya itu"

P : "Itu balok atau bangung lain?"

S3 : "Balok dengan yang, balok dengan ee, bentuk bangunan lain

P : "Okey dari soal no 1, apa yang ditanyakan?"

S3 : "Luas permukaan balok terpancung pada satuan luas"

P : "Rencana yang kamu gunakan untuk menjawab soal no 1 apa?"

S3 : "Mencari ee menghitung dari balok-balok kalau memasukkan kepada rumusnya yaitu 2 kali alas tambah dalam kurung keliling kali tinggi tutup kurung, lalu memasukkan angka-angkanya,"

P : "Tadikan kamu bilang bahwa 2 kali alas tambah keliling ditambah tinggi ya?"

S3 : "Dikali tinggi"

$\mathrm{P}$ : "Ohh dikali tinggi, nah angka-angka itu seperti 3, 4, itu dari mana?"

S3 : "Menghitung balok-baloknya pada gambar"

Oleh karena itu, berdasarkan hasil jawaban tertulis dan wawancara S3 tersebut dapat diidentifikasi bahwa S3 tidak melakukan kelima tahap Krulik dan Rudnick. Hal itu terjadi karena pada langkah awal yaitu tahap membaca dan berfikir saja S3 telah melakukan kesalahan dalam memahami soal atau masalah. Sehingga pada tahap selanjutnyapu S3 tidak dapat melanjutkan proses pemecahan masalah dengan benar.

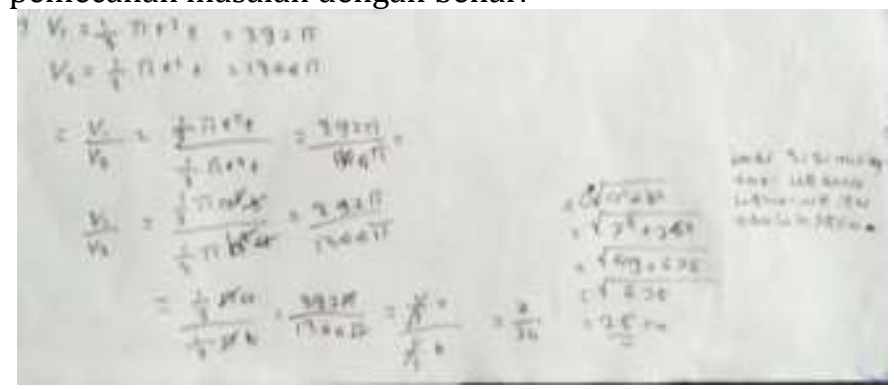

Gambar 7. Hasil Pekerjaan S3 Soal No 2

Berdasarkan hasil pekerjaan S3 diatas, untuk mencari panjang sisi miring segitiga atau $c$, langkah awal yang dilakukan S3 yaitu menuliskan bahwa terdapat 2 kerucut, diantaranya kerucut pertama memiliki volume $392 \pi \mathrm{cm}^{3}$ dan kerucut kedua memiliki volume $1344 \pi \mathrm{cm}^{3}$. Kemudian langkah selanjutnya S4 membuat rencana dengan menggunakan rumus volume kerucut yaitu $V=\frac{1}{3} \pi \cdot r^{2} \cdot t$, selain itu S3 juga menggunakan rencana lain dengan perbandingan. Berdasarkan gambar yang tertera pada soal sisi $a$ pada kerucut 1 merupakan jari-jaridan sisi $b$ pada kerucut 1 merupakan tinggi begitu pula sebaliknya pada kerucut 2, maka melalui rumus volume diatas S3 memanipulasi menjadi $V_{1}=\frac{1}{3} \pi \cdot b^{2} \cdot a=392 \pi$ dan $V_{2}=$ $\frac{1}{3} \pi \cdot a^{2} \cdot b=1344 \pi$. Kemudian S3 membandingkan kedua volume serta menyederhanakan angka atau huruf yang sama dengan cara mencoret atau menghilangkan. Hal itu terlihat dari hasil jawaban S3 yaitu $\frac{V_{1}}{V_{2}}=\frac{a}{b}=\frac{392}{1344}$ kemudian kedua volume dibagi dengan angka yang sama yaitu 56 sehingga nilai menjadi $\frac{V_{1}}{V_{2}}=\frac{a}{b}=\frac{7}{24}$. Berdasarkan hasil akhir S3 beranggapan bahwa sisi $a=7$ dan sisi $b=24$ sehingga untuk mencari sisi miring $c$, S3 menggunakan rumus Pythagoras dimana rumus tersebut adalah $c^{2}=\sqrt{a^{2}+b^{2}}$. Kemudian S3 memasukkan angka pada rumus tersebut sehingga $c^{2}=\sqrt{7^{2}+24^{2}}$, sehinggga sisi $c=\sqrt{625}=25$, jadi panjang sisi miring segitiga siku-siku tersebut adalah $25 \mathrm{~cm}$.

Mengacu pada jawaban tersebut dapat dikatakan bahwa S3 paham akan apa yang diketahui dan ditanyakan dari soal, S3 juga sudah memiliki gambaran atau rencana pada soal yang dikerjakan serta dapat mengimplementasikan keterampilan matematika dengan cara menghitung mundur untuk menemukan suatu jawaban. Hal ini diperkuat dengan petikan wawancara dengan S3 seperti berikut:

$\mathrm{P} \quad$ : "Rencana apa yang kamu gunakin untuk menjawab soal no 2?"

S3 : "Saya menggunakan cara perbandingan."

$\mathrm{P} \quad$ : "Silahkan dijelaskan bagaimana kamu mencarinya?"

S3 : "Volume 1 atau $V^{1}=\frac{1}{3} \pi r^{2} t=392 \pi, V_{2}=\frac{1}{3} \pi r^{2} t=$ $1344 \pi, \frac{V_{1}}{V_{2}}=\frac{\frac{1}{3} \pi r^{2} t}{\frac{1}{3} \pi r^{2} t}=\frac{392 \pi}{1344 \pi}$, lalu saya menggunakan huruf yang lain agar lebih mudah, $\frac{V_{1}}{V_{2}}=\frac{\frac{1}{3} \pi a^{2} b}{\frac{1}{3} \pi b^{2} a}=\frac{392 \pi}{1344 \pi}$."

$\mathrm{P} \quad$ : "Untuk huruf tadi yang kamu ganti itu yang diketahui pada soal atau kamu ganti sendiri?"

S3 : "Yang diketahui pada soal."

$\mathrm{P} \quad$ : "Okey lanjut silahkan jelaskan!"

S3 : "Sama dengan Phi per tigaa, dibanding sepertiga phi $b$, phi nya kita coret sama dengan $\frac{392 \pi}{1344 \pi}$, phi nya kita coret lagi dan satu per tiganya kita coret kita sederhanakan volumenya kedua kerucut tersebut. Sama dengan a itu a itu alas, yang b itu tinggi, kita kan mau mencari sisi miring jadi kita menggunakan rumus $c=\sqrt{a^{2}+b^{2}}$ sama dengan akar tujuh, ee tadi kan a ketemunya 7 , dan b ketemunya 24 ,

$\mathrm{P} \quad$ : “ "Oke bentar tadi kan masih bisa ketemu $\frac{392 \pi}{1344 \pi}$,kenapa pada akhirnya bisa berubah menjadi $\frac{7}{24}$ ?,"

S3 : "Di sederhanakan"

$\mathrm{P} \quad$ : "Bagaimana menyederhanakannya?"

S3 : "Dibagi bilangan yang sama"

$\mathrm{P}$ : "Dibagi bilangan yang sama, kemudian langkah selanjutnya?"

S3 : " $c=\sqrt{a^{2}+b^{2}}$ “

$\mathrm{P} \quad$ : "Lalu selanjutnya"

S3 : $\quad " \sqrt{7^{2}+24^{2}}=\sqrt{49+576}=\sqrt{625}$ akar dari 625 adalah 25 jadi sisi miring kedua ruas itu adalah $25 \mathrm{~cm}^{\prime \prime}$

P : "Okey apakah pada langkah kamu mencari jawaban ini kamu udh mengecek kembali?"

S3 : "Sudah"

$\mathrm{P}$ : "Berarti kamu sudah yakin ya"

S3 : "Iya"

Berdasarkan hasil jawaban tertulis dan wawancara S3 tersebut dapat diidentifikasi bahwa S3 telah melakukan usaha awal dalam memahami soal serta dapat menganalisis hal-hal yang perlu digunakan dalam proses pemecahan masalah dengan cara mengaitkan pada pengetahuan sebelumnya yaitu volume kerucut dan perbandingabn. Kemudian S3 menggunakan cara bekerja mundur atau mencoba mengerjakan melalui perhitungan dan penyederhanaan serta melakukan penarikan kesimpulan hasil jawaban yang berarti S3 telah melakukan pengecekan kembali. Sehingga dapat disimpulkan bahwa S3 mampu melewati kelima tahap Krulick dan Rudnik yaitu membaca dan berpikir dimana pada langkah ini S3 melakukan 
identifikasi fakta, pertanyaan, serta menjelaskan setting. Kemudian Mengeksplorasi dan merencanakan dinama S3 mengorganisasikan semua informasi yang di perlukan, Memilih suatu strategi dimana S3 mencoba mengerjakan serta menyederhanakan sehingga permasalahan menjadi lebih sederhana, Menemukan suatu jawaban dimana S3 menggunakan kemampuan berhitungnya dan meninjau kembali.

\section{Kemampuan Pemecahan Masalah S4}

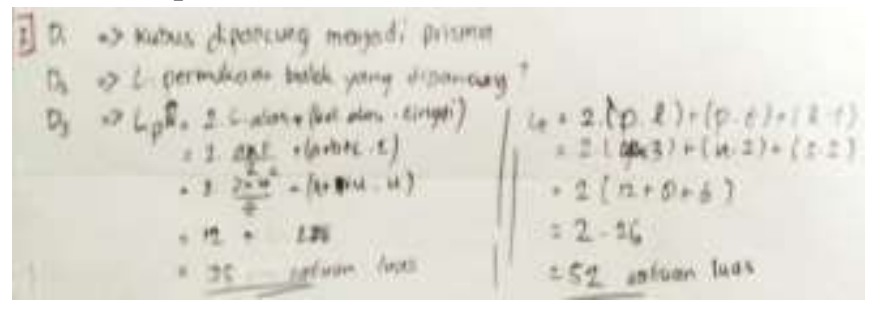

Gambar 8. Hasil Pekerjaan S4 Soal No 1

Berdasarkan hasil jawaban tertulis S4 diatas, S4 tidak dapat memahami soal dengan baik. Hal itu terlihat melalui proses dan hasil pemecahan masalah bahwa S4 yang hanya menghitung bangun pemancung. Langkah awal S4 adalah menuliskan apa yang ia pahami pada soal, bahwa terdapat sisi kubus (yang seharusnya balok) yang dipancung membentuk prisma. Kemudian S4 membuat rencana dengan menggunakan rumus luas balok yaitu 2 kali penjumlahan antara panjang kali lebar tambah panjang kali tinggi ditambah lebar kali tinggi. Masing-masing nilai panjang, lebar, dan tinggi didapatkan dengan menghitung tiap kubus satuan, namun S4 tidak menyebutkannya secara tertulis melainkan secara lisan, diantaranya adalah panjang 4 satuan, lebar 3 satuan dan tinggi 2 satuan. Keempat komponen tersebut dihitung berdasarkan prisma yang terbentuk pada balok. Kemudian S4 memasukkan angka kedalam rumus menjadi 2 dikali penjumlahan 4 kali 3, ditambah 4 kali 2, ditambah 3 kali 2. Sehingga, 2 dikali 26 sama dengan 52 satuan luas. Menurut S4 bangun yang terpancung adalah bangun yang membentuk prisma segitiga, namun bangun tersebut kurang tepat karena prisma pada gambar soal merupakan bangun pemancung. Sedangkan masalah yang ditanyakan dalam soal adalah luas balok yang terpancung. Mengacu pada jawaban tersebut dapat dikatakan bahwa S4 tidak paham akan apa yang diketahui dan ditanyakan dari soal. Hal ini diperkuat dengan petikan wawancara dengan S4 seperti:

$\mathrm{P} \quad$ : “Okey, nah apa yang ditanyakan pada soal no 1?"

S4 : "Luas permukaan balok yang terpancung"

$\mathrm{P} \quad$ : "Rencana apa yang kamu gunakan untuk menjawabn soal no 1?"

S4 : "Rencana saya adalah mencari luas permukaan dengan cara $2 \times(p l+p t+l t)$ "

$\mathrm{P}$ : "Silahkan dijelaskan bagaimana cara kamu menggunakan rumus itu?"

S4 : " $2 \times(4.3+4.2+3.2), 2 \times(12+8+6), 2 \times 26=52$ satuan luas."

$\mathrm{P} \quad$ : "Nah tadi kamu menyebutkan bahwa $2 \times(p l+p t+$ lt) nah, angka-angka yang kamu masukkan dari 3, 4, 2 itu dari mana?"

S4 : "Darigambar tersebut"

P : "Cara kamu, kan disitu tidak tertuliskan bahwa ini 2, ini 3, ini 4. Nah cara kamu gimana menentukan angka-angka itu?"

S4 : "Ada kotak kecil dan itu lalu dihitung."

$\mathrm{P} \quad$ : "Berarti kamu menghitung jumlah kotaknya begitu?"

S4 : "Iya"
P : "Oke, kan tadi udah apakah itu udah ketemu jawaban akhirnya?"

S4 : "Udah"

$\mathrm{P} \quad$ : "Sebelumnya kamu udah mengecek kembali belum?"

S4 : "Sudah"

$\mathrm{P} \quad$ : "Berarti kamu udah yakin dengan jawaban kamu?"

S4 : "Yakin"

Oleh karena itu, berdasarkan hasil jawaban tertulis dan wawancara S4 tersebut dapat diidentifikasi bahwa S4 tidak melakukan kelima tahap Krulik dan Rudnick. Hal itu terjadi karena pada langkah awal yaitu tahap membaca dan berfikir saja S4 telah melakukan kesalahan dalam memahami soal atau masalah. Sehingga pada tahap selanjutnyapu S4 tidak dapat melanjutkan proses pemecahan masalah dengan benar.

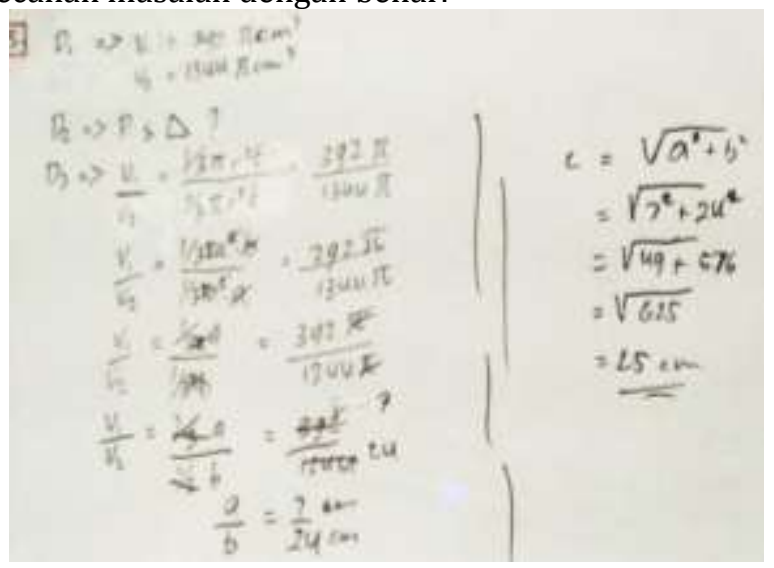

Gambar 9. Hasil Pekerjaan S4 Soal No 2

Berdasarkan hasil pekerjaan S4 diatas, untuk mencari panjang sisi miring segitiga atau $c$, langkah awal yang dilakukan S4 yaitu menuliskan bahwa terdapat 2 kerucut, diantaranya kerucut pertama memiliki volume $392 \pi \mathrm{cm}^{3}$ dan kerucut kedua memiliki volume $1344 \pi \mathrm{cm}^{3}$. Kemudian langkah selanjutnya S4 membuat rencana dengan menggunakan rumus volume kerucut yaitu $V=\frac{1}{3} \pi \cdot r^{2} \cdot t$, selain itu S4 juga menggunakan rencana lain dengan perbandingan. Berdasarkan gambar yang tertera pada soal sisi $a$ pada kerucut 1 merupakan jari-jaridan sisi $b$ pada kerucut 1 merupakan tinggi begitu pula sebaliknya pada kerucut 2, namun menurut pendapat S4 pada saat memanipulasi menjadi $V_{1}=\frac{1}{3} \pi \cdot b^{2} \cdot a=392 \pi$ dan $V_{2}=$ $\frac{1}{3} \pi \cdot a^{2} \cdot b=1344 \pi$ huruf tersebut $\mathrm{S} 4$ ganti dengan alasan mengarang. Kemudian S4 membandingkan kedua volume serta menyederhanakan angka atau huruf yang sama dengan cara mencoret atau menghilangkan. Hal itu terlihat dari hasil jawaban S4 yaitu $\frac{V_{1}}{V_{2}}=\frac{a}{b}=\frac{392}{1344}$ kemudian kedua volume dibagi dengan angka yang sama yaitu 56 sehingga nilai menjadi $\frac{V_{1}}{V_{2}}=\frac{a}{b}=\frac{7}{24}$. Berdasarkan hasil akhir S4 beranggapan bahwa sisi $a=7$ dan sisi $b=24$ sehingga untuk mencari sisi miring $c$, S4 menggunakan rumus Pythagoras dimana rumus tersebut adalah $c^{2}=\sqrt{a^{2}+b^{2}}$. Kemudian S4 memasukkan angka pada rumus tersebut sehingga $c^{2}=\sqrt{7^{2}+24^{2}}$, sehinggga $\operatorname{sisi} c=\sqrt{625}=25$, jadi panjang sisi miring segitiga siku-siku tersebut adalah $25 \mathrm{~cm}$.

Mengacu pada jawaban tersebut dapat dikatakan bahwa S4 belum sepenuhnya paham akan apa yang diketahui dari soal, S4 juga sudah memiliki gambaran atau rencana pada soal yang dikerjakan serta dapat mengimplementasikan keterampilan matematika dengan cara menghitung mundur 
untuk menemukan suatu jawaban. Hal ini diperkuat dengan petikan wawancara dengan S4 seperti berikut:

\begin{tabular}{|c|c|c|}
\hline $\mathrm{P}$ & : & $\begin{array}{l}\text { "Untuk soal no 2, apa aja yang kamu ketahui dari } \\
\text { soal no 2?" }\end{array}$ \\
\hline S4 & : & "Volume kerucut 1 dan kerucut 2 " \\
\hline $\mathrm{P}$ & : & "Berapa?" \\
\hline S4 & : & $\begin{array}{l}\text { "Volume kerucut } 1 \text { adalah } 392 \pi \mathrm{cm}^{3} \text { dan volume } \\
\text { kerucut } 21344 \pi \mathrm{cm}^{3} \text { " }\end{array}$ \\
\hline $\mathrm{P}$ & : & "Trus yang ditanyakan apa?" \\
\hline S4 & : & "Panjang sisi miring segitiga siku-siku tersebut" \\
\hline$P$ & : & $\begin{array}{l}\text { "Rencana apa yang kamu guinakan untuk mencari } \\
\text { jawaban soal no 2?" }\end{array}$ \\
\hline S4 & : & "Dengan perkalian silang," \\
\hline $\mathrm{P}$ & : & $\begin{array}{l}\text { "Dengan perkalian silang, jelaskan bagaimana kamu } \\
\text { mencari jawabannya?" }\end{array}$ \\
\hline S4 & : & "Emmhh... $\frac{V_{1}}{V_{2}}=\frac{\frac{1}{3} \pi r^{2} t}{\frac{1}{3} \pi r^{2} t}=\frac{392 \pi}{1344 \pi}, \frac{V_{1}}{V_{2}}=\frac{\frac{1}{3} \pi a^{2} b}{\frac{1}{3} \pi b^{2} a}=\frac{392 \pi}{1344 \pi}$ \\
\hline $\mathrm{P}$ & : & "Kok bisa berubah? $r^{2} t$ bisa berubah menjadi $a^{2} b ?{ }^{3}$ \\
\hline S4 & : & "Kita menggunakan huruf imbuhan" \\
\hline $\mathrm{P}$ & : & $\begin{array}{l}\text { "huruf imbuhan itu kamu mencari atau mengarang } \\
\text { sendiri atau dari soal atau gimana?" }\end{array}$ \\
\hline S4 & : & "Untuk mencari alas dan tinggi" \\
\hline $\mathrm{P}$ & : & $\begin{array}{l}\text { "Iya, huruf itu kamu pakai itu kamu ngarang atau } \\
\text { kamu ambil dari soal?" }\end{array}$ \\
\hline S4 & : & "Ngarang sendiri" \\
\hline $\mathrm{P}$ & : & "Owh ngarang sendiri,lalu teruskan!" \\
\hline S4 & : & "Emmh $. . \cdot \frac{V_{1}}{V_{2}}=\frac{\frac{1}{3} a}{\frac{1}{3} b}=\frac{392 \pi}{1344 \pi}$, v nya kedua v harus dicoret" \\
\hline $\mathrm{P}$ & : & "Kenapa harus dicoret?" \\
\hline S4 & : & "Agar mudah mencarai alas dan tingginya" \\
\hline $\mathrm{P}$ & & “Lalu?” \\
\hline S4 & : & “. $\frac{V_{1}}{V_{2}}=\frac{\frac{1}{3} a}{\frac{1}{3} b}=\frac{392}{1344}, "$, \\
\hline $\mathrm{P}$ & $:$ & "Lalu" \\
\hline S4 & : & "Kita membagi volume dengan angka yang sama" \\
\hline $\mathrm{P}$ & : & "Lalu” \\
\hline S4 & : & “Lalu ketemunya alasnya 7 dan tingginya $24 \mathrm{~cm} "$ \\
\hline$P$ & : & $\begin{array}{l}\text { "Kemudiuan Apakah itu sudah ketemu jawaban } \\
\text { akhirnya?" }\end{array}$ \\
\hline S4 & $:$ & "Belum" \\
\hline $\mathrm{P}$ & : & "Lalu langkah selanjutnya gimana?" \\
\hline S4 & : & $\begin{array}{l}\text { "Kita harus mencari sisi miringnya dengan cara } \\
\sqrt{a^{2}+b^{2}}=\sqrt{7^{2}+24^{2}}=\sqrt{47+576}=\sqrt{625} \text { dan } \\
\text { hasilnya menjadi } 25 \text {, akar dari } 625 \text { adalahh } 25 \mathrm{~cm}\end{array}$ \\
\hline $\mathrm{P}$ & $:$ & "Jadi, 25 cm itu apanya?" \\
\hline S4 & : & "Kemiringan, Sisi miring" \\
\hline
\end{tabular}

Berdasarkan hasil jawaban tertulis dan wawancara S4 tersebut dapat diidentifikasi bahwa S4 telah melakukan usaha awal dalam memahami soal serta dapat menganalisis hal-hal yang perlu digunakan dalam proses pemecahan masalah dengan cara mengaitkan pada pengetahuan sebelumnya yaitu volume kerucut, perbandingan dan teorema pythagoras. Kemudian S4 menggunakan cara bekerja mundur atau mencoba mengerjakan melalui perhitungan dan penyederhanaan namun S4 tidak melakukan penarikan kesimpulan hasil jawaban yang berarti S4 tidak melakukan pengecekan kembali. Sehingga dapat disimpulkan bahwa S4 hanya mampu melakukan keempat tahap Krulick dan Rudnik yaitu membaca dan berpikir walaupun S4 hanya melakukan beberapa identifikasi soal, pertanyaan, serta menjelaskan setting. Kemudian mengeksplorasi dan merencanakan dinama S4 mengorganisasikan semua informasi yang di perlukan, memilih suatu strategi dimana S4 mencoba mengerjakan serta menyederhanakan sehingga permasalahan menjadi lebih sederhana, dan menemukan suatu jawaban dimana S4 menggunakan kemampuan berhitungnya, namun S4 tidak melakukan peninjauan kembali.

\section{SIMPULAN DAN SARAN}

Berdasarkan pembahasan diatas dapat disimpulkan bahwa siswa berkemampuan tinggi dalam proses pemecahan masalah soal olimpiade nomor 1 semua subjek tidak dapat melakukan kelima tahap Krulik dan Rudnick. Hal itu terjadi karena pada langkah awal yaitu tahap membaca dan berfikir saja subjek telah melakukan kesalahan dalam memahami soal atau masalah. Sehingga pada tahap selanjutnya subjek tidak dapat melanjutkan proses pemecahan masalah dengan benar. Sedangkan untuk soal nomor 2 terdapat 3 dari keempat subjek yang mampu melewati kelima tahap Krulick dan Rudnik yaitu membaca dan berpikir dimana pada langkah ini subjek melakukan identifikasi fakta, pertanyaan, serta menjelaskan setting. Kemudian mengeksplorasi dan merencanakan dinama subjek mengorganisasikan semua informasi yang di perlukan, memilih suatu strategi dimana subjek mencoba mengerjakan serta menyederhanakan sehingga permasalahan menjadi lebih sederhana, menemukan suatu jawaban dimana subjek menggunakan kemampuan berhitungnya dan meninjau kembali. Namun terdapat 1 subjek yang tidak dapat menyelesaikan tahap nomor 5 pada teori Krulik dan Rudnick yaitu refleksi dan pengembangan (reflect and extend), dimana pada tahap ini subjek mengecek kembali jawabannya dan melihat variasi dari cara memecahkan masalah.

Berdasarkan simpulan diatas, maka dapat di sampaikan masukan kepada peneliti lain, guru dan siswa. Bagi guru, hendaknya mempertimbangkan hasil penelitian ini sebagai acuan metode pembelajaran untuk meningkatkan pemahaman dan kemampuan pemecahan masalah matematika bagi siswa, serta memberikan banyak latihan soal pemecahan masalah agar siswa terbiasa. Bagi siswa, hendaknya memperbanyak latihan soal pemecahan masalah. Bagi siswa yang masih mengalami kesulitan hendaknya menuliskan hal-hal yang terkandung setelah membaca dan berpikir dengan mencatat kata kunci, bertanya kepada siswa lain apa yang sedang ditanyakan pada masalah, atau menyatakan kembali masalah ke dalam bahasa yang lebih mudah dipahami, eksplorasi dan merencanakan yang berarti mengidentifikasi masalah yang diberikan, menyajikan masalah ke dalam cara yang mudah dipahami, memilih strategi dengan menarik kesimpulan atau membuat hipotesis mengenai bagaimana cara menyelesaikan masalah yang ditemui berdasarkan apa yang sudah diperoleh pada dua tahap pertama, mencari jawaban dengan menggunakan semua keterampilan matematika seperti menghitung untuk menemukan suatu jawaban, dan refleksi dan pengembangan dengan mengecek kembali jawabannya dan melihat variasi dari cara 
memecahkan masalah. Bagi peneliti lain, dapat menggunakan penelitian ini sebagai dasar penelitian tindakan kelas ataupun penelitian lainnya.

\section{UCAPAN TERIMA KASIH}

Penulis mengucapkan terima kasih kepada dosen pembimbing, guru matematika serta siswa kelas IX SMA Negeri 8 Salatiga yang telah membantu dalam menyelesaikan penelitian ini.

\section{DAFTAR RUJUKAN}

[1] Depdiknas. 2006. Permendiknas No 22 Tahun 2006 Tentang Standar Isi. Jakarta : Depdiknas.

[2] Dimyati dan Mujdiono. 2009.Belajar dan Pembelajaran. Jakarta: Rineka Cipta.

[3] Harahap E.R \& Edi S. 2017. Kemampuan Pemecahan Masalah Matematis Siswa Kelas VII Dalam Menyelesaikan Persamaan Linear Satu Variabe. Jurnal FKIP. UNIMED, 7(1) 44. Online. Tersedia. https://onlinejournal.unja.ac.id/index.php/edumatica/article/download/3 874/2823.

[4] Handayani D \& Rusdiana A. 2016. Pengembangan Permainan Tebak Kata Sebagai Media Pembelajaran Pada Materi Kimia Unsur (Development Charades Game As A Learning Media In Chemical Elements Topic). Jurnal FMIPA. Universitas Negri Surabaya, 5(2) $333 . \quad$ Online. Tersedia http://ejournal.unesa.ac.id/article/19396/36/article.pdf.

[5] Murdiana Nyoman. 2015. Pembelajaran Pemecahan Masalah Dalam Pembelajaran Matematika. Jurnal FKIP. Universitas $\begin{array}{llll}\text { Tadulako. } & 4(1) . & \text { Online. } & \text { Tersedia }\end{array}$ http://jurnal.untad.ac.id/jurnal/index.php/AKSIOMA/article /viewFile /7706/6076.

[6] Purnomo, Eko Andy dan Mawarsari, Venissa Dian. 2014. Peningkatan Kemampuan Pemecahan Masalah Melalui Model Pembelajaran Ideal Problem Solving Berbasis Project Based Learning. Jurnal FKIP. Universitas Muhammadiyah Semarang.

[7] R Rohisah Verial, dkk. 2014. Pengembangan Perangkat Pembelajaran Matematika Berbasis Karakter Pada Model Pembelajaran Penemuan Terbimbing (Guided Discovery) Pokok Bahasan teorema PythagorasUntuk Smp Kelas VIII. Jurnal FKIP. Universitas Jember, 5(2), 101-102. Online. Tersedia https://jurnal.unej.ac.id/index.php/kadikma/article/downlo $\mathrm{ad} / 1365 / 1118$.

[8] Sadiman, Arif. 1986. Media Pendidikan, Pengertian, Pengembangan, dan Pemanfaatannya. Jakarta: Rajawali.

[9] Sugiyono. 2013. Metode Penelitian Pendidikan Pendekatan Kuantitatif, Kualitatif, dan R \& D. Alfabeta: Bandung.

[10] Wahyudi \& Inawati Budiono. 2012. Pemecahan Masalah Matematika. Salatiga: Widya Sari Press. 